\title{
Comparative studies on growth performance of indigenous calves fed with different concentrate mixture
}

\author{
RAJAN MISHRA, S.P. NAGE, R. R. SHELKE, S.D. CHAVAN, HEMANT KUMAR AND P. A. KAHATE
}

\begin{abstract}
The present study was undertaken to evaluate the comparative studies on growth performance of indigenous calves fed with different concentrate mixture. Fifteen indigenous calves were selected and divided into three groups on the basis of nearness to age and body weight. Feeding trials were conducted with three treatments viz., $\mathrm{T}_{1}$ - Readymade concentrate (Sugras), $\mathrm{T}_{2}$ - homemade concentrate-I, $\mathrm{T}_{3}$ - homemade concentrate - II and in all the treatments dry fodder was fed ad. lib and quantity of green fodder + concentrate mixture was provided as per requirement of the basis of feeding standards. It was observed that the higher CP (19.28\%) and EE (4.05\%) in homemade concentrate-I while, homemade concentrate-II was higher in CF (12.24\%) and NFE (60.49). The daily dry matter intake per $100 \mathrm{~kg}$ body weight of indigenous calves was higher in $\mathrm{T}_{2}$ followed $\mathrm{T}_{1}$ and $\mathrm{T}_{3}$ treatments. The highest total $\mathrm{kg} /$ day/ head body weight gain of indigenous calves was observed in treatment $\mathrm{T}_{2}(0.392)$, followed by $\mathrm{T}_{3}(0.336)$ and lowest in treatment $\mathrm{T}_{1}(0.313)$. Same trends were noticed in respect to viz., height, length and chest girth of calves. The feeding cost $/ \mathrm{kg}$ body weight gain was lowest in $\mathrm{T}_{2}$ followed by $\mathrm{T}_{3}$ and $\mathrm{T}_{1}$ treatment. It was concluded from the results that the feeding of homemade concentrates-I (Maize 30 \% + GNC 20\% + Wheat bran 28\% + Turchuni 20\% + Minerals mixture 1\% + Common salt 1\%) was economical for better growth performance of indigenous calves.
\end{abstract}

KEY WORDS : Readymade concentrate, Homemade concentrate, Indigenous calves, Adlibitum, Crude protein, Dry matter intake, Body weight

How TO CITE THIS PAPER : Mishra, Rajan, Nage, S.P., Shelke, R.R., Chavan, S.D., Kumar, Hemant and Kahate, P.A. (2017). Comparative studies on growth performance of indigenous calves fed with different concentrate mixture. Res. J. Animal Hus. \& Dairy Sci., 8(2) : 113-118 : DOI: 10.15740/HAS/RJAHDS/8.2/113-118.

Address for correspondence :

Rajan Mishra, Department of Animal Husbandry and Dairy Science, Dr. Panjabrao Deshmukh Krishi Vidyapeeth, AKOLA (M.S.) INDIA

Associated Authors':

S.P. Nage, R. R. Shelke, S.D. Chavan, Hemant Kumar and P. A. Kahate, Department of Animal Husbandry and Dairy Science, Dr. Panjabrao Deshmukh Krishi Vidyapeeth, AKOLA (M.S.) INDIA 